\title{
Innovative Programmes for Gender Equality in Indian School Education
}

\author{
Sarbjit Kaur \\ Department of Education \& Community Service, Punjabi University, Patiala, Punjab-147002, India
}

sarbscience@gmail.com

\section{ARTICLE INFORMATION}

Received: August 05, 2020

Revised: August 31, 2020

Accepted: September 17, 2020

Published Online: October 21, 2020

\section{Keywords:}

Free and Compulsory Education, Gender Gaps, Gender-Inclusion Fund, Literacy Rate,

National Education Policy 2020, Sustainable Development Goals

\begin{abstract}
Background: National Education Policy 2020 aims to eliminate existing disparities in access to education for children from any gender or any under-represented group. After independence, India makes considerable strides in reducing gender gaps in education, but even today the goal of gender parity in school enrolments remains elusive. India provides Universal Elementary Education to all and this commitment has been articulated through Constitution, National Education Policies and other Innovative Programmes. All these initiatives put a strong emphasis on the education of girls and some of the programmes have been started particularly to eliminate gender gaps in school education.

Purpose: This paper is an attempt to review the Innovative Programmes started by the Government of India to redress the gender gaps in school education and also to analyze the impact of these programmes on female literacy rates and enrolment rates of girls in elementary education. Before analyzing the innovative programmes and their impact on educational statistics, the paper briefly assesses the status of education in the Constitution of India and also studies the national policy perspective regarding universal elementary education of girls in the country in order to provide a sound background to this study.

Methods: The method of document analysis for the review of policy documents and innovative programmes has been utilized and trend analysis method has been applied to study the educational statistics from the year 1950 to 2015.

Results: The female literacy rates and enrolment of girls in total enrolments for the classes VI-VIII have registered an increase after the implementation of these programmes.

Conclusions: It has been observed that these community-based programmes of the country have received a lot of international recognition for their contribution towards reducing gender gaps in elementary education. So, the experiences of these Innovative Programmes can prove quite beneficial for other countries struggling with gender gaps in school education.
\end{abstract}

\section{Focus of the Study}

The latest development regarding education in India i.e. National Education Policy (NEP), 2020 recognised that there are large disparities concerning gender and social category in all levels of school education. Like the Samagra Shiksha Abhiyan, NEP also aims to bridge the gender gaps in school education (GOI, 2018; MHRD, 2020). These gaps within the education system remain a major obstacle in the realisation of the goal of 'Education for All' in India. The NEP recommended creating 'Gender-Inclusion Fund' to provide quality and equitable education for all girls as well as transgender students. This Fund will assist the States to provide proper sanitation and separate toilet facilities in the school and even help these States in conditional cash transfer policies to increase the access to education among girls. This fund will also support the States for the community-based initiatives started to redress the gender and social gaps in access to education. As per the guidelines of Global Policy Perspective especially the Sustainable Development Goals, NEP 2020 also aims to provide quality and equitable education for all from Grade 1 to Grade 12. Besides enrolments, NEP put a strong emphasis on Learning for All (MHRD, 2020). However, in India, the literacy rate of females and enrolment of girls in school education are both comparatively less as compared to males (Kesarwani \& Komaraiah, 2019). And this gender gap poses a serious challenge in achieving gender equality in 
education in the country. This study is an attempt to study the government initiatives regarding free and compulsory education in India and their impact on the female literacy rates and enrolment rates of girls in elementary education. And the main objectives of this study include:

- To assess the status of Education in the Constitution of India.

- To study the national policy perspective regarding universal elementary education of girls.

- To explore the various Innovative Programmes started by Government of India regarding free and compulsory education of all especially girls

- To trace the changes in the female literacy rates and enrolments rates in class VI-VIII from 1951 to 2015.

\section{Methodology of the Study}

In this study, document analysis and trend analysis methods of educational research have been applied. The method of document analysis for the study of the constitution and educational policies has been employed. Document analysis means a systematic procedure for examining or reviewing documents related to the project or study and then interpreting these to understand the underlying concept (Bowen, 2009). To trace the change in female literacy rates and school enrolments of girls at the elementary level of education, the method of trend analysis has been used. The Trend analysis is considered as an interesting application of descriptive research as it is used to indicate that what has been happened in past, what the present situation reveals and based on this what will happen in the near future (Best \& Kahn, 2007).

Both primary and secondary sources related to the study have been utilized. The primary sources such as the Constitution of the country, education policy documents of the Government of India and educational statistical reports published by the Government of India have been used. Besides these, secondary sources, such as international reports and research studies related to innovative programmes, have also been utilized. The paper is divided into three main sections: In the first section, the status of education in the Constitution of the country and national education policies regarding universal elementary education of girls have been analysed; the second section reviews the innovative programmes started to redress the gender gaps in elementary education and third section, female literacy rates and enrolment of girls in elementary education have been presented in a tabular form followed by a brief discussion.

\section{Constitutional Provisions and National Policy Perspective Regarding Universal Elementary Education}

Education for all is critical for the development of any nation and have been emphasised in various international and national agreements. Education is recognized across the world as a powerful and indispensable tool to enhance the process of human development and social progress. The economic conditions of an individual as well as countries improve with the achievement of education. Parallel to it, education is critical for building of the democratic society; education provides political voice and social empowerment to the people. The positive effects of education on human beings can be easily seen in all the aspects of life such as individual, cultural, social, economic and political aspects (Dreze \& Sen, 2013; Bhat, 2013; Kaur, 2018).

Education is a fundamental human right for all including girls. The various international agreements like Universal Declaration of Human Rights 1948 coupled with the endorsement of global goals, such as Education for All (EFA), Millennium Development Goals (MDGs) and Sustainable Development Goals, by developing countries have strongly supported remarkable changes in the educational policy planning by making primary education fee-free. Following these goals, approximately 82 per cent of national constitutions contain a provision for the right of education for all (UNESCO, 2017). With all these efforts, significant progress in the expansion of education for all has been noticed in the recent years, but even today the females are less educated than males and face inequality in other areas also. Gender Inequality in India, as well as in other countries of South Asia, is a serious concern as the system of patriarchy in these countries limit and confine females to subordinate roles (UNDP, 2016). 
There has been a lot of discrimination against females and discrimination starts before the birth of the child and so the number of females as compared to males in the population is also less in such countries. It has also highlighted that gender inequality in education is simply one aspect of systematic discrimination against females (UNESCO, 2003). Gender inequality is one of the greatest barriers to human development (UNDP, 2016). Like other developing countries, the literacy rates of the female population in India are also less as compared to male population (Kesarwani \& Komaraiah, 2019). The female literacy rates for all ages were 62 per cent and on the other hand, male literacy rates were 75.7 per cent in 2014. No doubt the gender gap between the literacy rate has decreased but there still exists a gap of 13.7 per cent in the literacy rates of males and females (MHRD, 2018). The females tend to fare quite badly in education as compared to males. Education in the Constitution of India

The Government of India, since the inception of the Republic, has accepted the role of universal elementary education for strengthening the democracy and for nation-building, and so free and compulsory education has been offered to all children as a constitutional commitment. By setting a time limit to achieve the goal of free and compulsory education, India became the first country to set the time frame for the attainment of educational goals (King, 2016). The time limit to achieve this goal was 1960 but this target date has been revised several times and even today India fails to achieve the goal of universal elementary education. Besides this, Article 15 ensures that there will be no discrimination based on religion, race, caste, sex, place of birth or any of them. Further, the Constitutional Amendment Act was enacted by Parliament in December 2002 to amend the Constitution of India and known as Constitution (Eighty-six Amendment) Act, 2002. This Constitutional Amendment was the result of the Unni Krishnan Judgement of the Supreme Court in 1993 which held that children under the age of 14 years have the fundamental right to free education. As a result of this judgement, the State inserted Article 21 A after Article 21 of the Constitution which stipulates that the State shall provide free and compulsory education to all children of the age of 6 to 14 years in such a manner as the State may, by law, determine. The Constitution of India grants the right to education to all children aged between 6 to 14 years irrespective of gender, caste, state, ethnicity etc. (GOI, 2019).

The government of India remains quite proactive in its efforts towards the free and compulsory education for all and time to time various commissions and policies have been framed to expand the access of education for all. The first commission namely Education Commission appointed by the Government of India to examine comprehensively almost all aspects of education was set up in 1964 under the chairmanship of Prof. D.S. Kothari. Education Commission submitted its report in 1966 and considered as a major landmark in the history of education in India. The Commission realized the critical role of education in social and economic development and so suggested a Common School System of public education to provide an equitable education to all children irrespective of the caste, creed and economic status of the individuals. As early as the 1960s, the Commission had observed that there is segregation in the education system in the country and for quality education in public school, it was recommended that allocations of national income towards education must be increased to realize the Constitutional promise of Education for All (GOI, 1966).

India intensified the efforts to achieve the goal of universal elementary education with the National Policy on Education 1986 and Programme of Action (1992). The Policy gives critical priority to the universalization of elementary education and realized that education is fundamental for all-round development. The policy considered education as a unique investment in the present and the future. And so, the policy will lay special emphasis on the removal of disparities and equalize educational opportunity by attending to the specific needs of those who have been denied equality so far. Education will be used as an agent of basic change in the status of women. The highest priority in this policy is given to the participation of children especially girls from the schedule caste and schedule tribe families, the problem of dropping out of school and also to the working children. So, it has been stated that the non-formal education for school drop-outs, for children from habitations which lack schools, working children and girls who cannot attend wholeday schools, will be strengthened and enlarged. The policy resolved that special priority will be given to the solution of the problem of drop-outs and to ensure the retention of children in the school. It resolved that 
free and compulsory education of satisfactory quality is provided to all children up to 14 years of age before we enter the twenty-first century (GOI, 1986).

The next turning point in the development of education in India is the RTE Act, 2009. The Right of Children to Free and Compulsory Education Act, 2009, popularly known as the RTE Act, was legislated on August $4^{\text {th }}, 2009$ and comes into force on April $1^{\text {st }}, 2010$. The Government of India notify the $86^{\text {th }}$ Constitutional Amendment by passing this legislation in 2009 and this is a significant development in the education system of the country. With this Act, the country joined other 135 countries in the world, having education as a fundamental right to every child. The Act gives the right to all children aged between six to fourteen years for free and compulsory education in the neighborhood school till the completion of the elementary education.

The latest National Education Policy 2020 also put a strong emphasis on the education of girls and states that prejudice and bias based on gender and other such factors affect people's capacity to benefit from the education system. Education is an important tool for achieving social justice and equality in the society and so inclusive and equitable education for all including girls and transgender students is critical. Further, it has been stated that NEP aims to eliminate any remaining disparity in access to education for children from any gender (MHRD, 2020). The policy appreciated the efforts of SSA and RTE Act for achieving nearly universal enrolments in primary education and also for reducing the gender gaps in elementary education. It also extends the coverage of RTE Act from 6 to 14 years to all children between 3 to 18 years to reduce gender gaps in secondary education. The inclusion of early childhood care and education in free and compulsory education is the most prominent feature of this policy as it has been considered that this level of education plays a critical role in the learning of students in further education. The Policy gives due consideration to the needs of all children especially girls and transgender students in all level of education (ibid.)

\section{Innovative Programmes to Reduce Gender Gaps in Education}

In addition to the above-mentioned policy planning, the Government of India with the help of international assistance has also started various initiatives. The most important and comprehensive of these initiatives is the 'Education for All' or Sarva Shiksha Abhiyan. It is a flagship programme started by the Government of India to improve the quality of elementary education in the country. It has been operational since 20002001 and has its roots in District Primary Education Programme, 1994. The main aim of the programme is to bridge the social, gender and regional facets of education. The time-bound and integrated approach have been introduced through this programme to achieve the universalization of elementary education in the country. The programme has been considered as a national movement for qualitative and comprehensive elementary education by providing interventions such as universal access and retention, eliminating gender and social gaps in elementary education and also for improving the quality of learning at this level of education. It is considered as a vehicle to operationalize the RTE Act (Jha \& Parvati, 2014). In addition to this, the following innovative programmes have been started with community participation to eliminate the prevailing inequalities in the access of education:

\subsection{Shiksha Karmi Project}

Shiksha Karmi Project was started in Rajasthan and sponsored collaboratively by Swedish International Development Agency (SIDA) and Government of India and State of Rajasthan. Shiksha Karmi means education worker who was less qualified than a regular teacher but specially trained to solve the problem of teacher absenteeism. It has been considered as an innovative primary education project to address the problem of teacher absenteeism. The problem of teacher absenteeism has been considered as a major obstacle in the way of universalisation of elementary education and to tackle this problem an innovative and unique scheme of training local para-teachers known as Shiksha Karmi has been collaboratively launched. The SKP aimed at the universalisation and qualitative improvement of primary education in the remote, rural and economically backward areas of the state where formal primary schools were either nonexistent or dysfunctional.

The provision of quality basic education to girls, schedule caste and tribes, other marginalised sections of the society was the main objective of the project. The core idea of the project was based on the supposition 
that a change agent or a para-teacher can work effectively if he/she belongs to the same community. Furthermore, the teacher's willingness and ability to function as a social worker have been considered more important than the educational qualification. It has been reported that the project has improved the enrolment, attendance and retention rates and the performance of these students was also comparable with the students form regular primary schools. The project has been successful in the enrolment of children from schedule caste and tribes but not so effective in reducing the gender gap, however, this project was considered as one of the most successful projects of the country (Ramachandran and Sethi, 2001). But the success of the project was undermined by the discriminatory attitude towards women by some of the project leader (UNESCO, 2015)

\subsection{The Mahila Samakhya Programme (Education for Women's Equality)}

The Mahila Samakhya Programme (Education for Women's Equality) was launched in 1989 with the financial assistance of the Government of the Netherlands to pursue the objective of women empowerment through their participation in the education process. Government of India now funds the programme since 2005-06. The National Policy on Education 1986 and Programme of Action 1992 recognised that the empowerment of women is possible with the most critical pre-condition for the participation of girls and women in the educational process. Moreover, this Mahila Samakhya Programme was launched for the education and empowerment of women in rural areas, particularly of socially and economically disadvantaged sections of the society. In 2014, the programme covered 130 districts and 679 blocks in the country. It has laid the foundation of women empowerment at the grassroot level with the organisation of Mahila Sanghas and changed the outlook of rural women. The Mahila Sanghas are responsible for setting the agenda and priorities of this programme.

The programme recognised the centrality of education for women empowerment and adopted an innovative approach towards the process of education. Education is not considered as something to acquire basic literacy skills but rather than a process to learn to question, critically analysing issues and problems and to find solutions. Regarding the role of this programme in Women Empowerment, the EFA Global Monitoring Report 2002 pointed out that the programme has a community participation approach and it initiates a process of critical questioning and analysing among women to enable them to use their existing knowledge and skills in an efficient way (UNESCO, 2002). The programme has organic linkages with other schemes launched for the universalisation of education such as DPEP and SSA and plays an active role in the removal of barriers to the participation of girls/women in the education system by running alternative schooling facilities.

The programme plays a proactive role in ensuring the greater access to education for girl children, generating demand for education by strengthening the abilities of women to play an active and effective role in the education system at the village level. The programme is being implemented in the form of non-formal education centres, early childhood and pre-schoolcum-creche facilities for working women in the villages. Besides these issues, the programme also addresses issues like gaining control over health and nutrition, seeking literacy for themselves and their daughters, meeting minimum daily needs, actively accessing and controlling resources, improving civic amenities, participation in local governance etc. It has been pointed out that the programme has succeeded in achieving the objective of women empowerment by educating girls and women at their own pace (Jain and Kumar, 2013).

\subsection{Lok Jumbish (People's Movement for Education for all) Programme}

Lok Jumbish (People's Movement for Education for all) Programme was an innovative and joint initiative of Government of Rajasthan and local NGOs started in 1992 with assistance from Swedish International Development Agency (SIDA) to achieve the goal of universalization of elementary education through mass mobilization and participation of people. The basic idea of the programme was to address the problem of low community interest in education by stressing the participation of community members in the school mapping process. The goals of the programmes include universalization of primary education, the drastic reduction in illiteracy, make education an instrument of women empowerment, improving the content and process of education to relate it the local environment of people etc. The project was an area-based approach 
to address the learning needs of every single child in the village and priority was given to the children who belong to the communities marginalized from centuries. The girls from these deprived sections of the society emerged as the center-stage in the focus of the project and particular emphasis was placed on the equal participation of women in decision making at all levels. The objective was education as an agent of basic change in the status of women.

It has been pointed that the education system of Rajasthan needs a drastic transformation as the female literacy rate in the state was quite less and the access to education for girls from marginalized sections of the society also require improvement. The programmes such as Shiksha Karmi and Lok Jumbish gained international attention and were considered quite effective for the universalization of elementary education in the state. The main goals of this project were providing access to primary education for all children in the age group of 5 to 14 years in regular schools and whenever necessary in the Sahaj Shiksha Centers, ensuring the attendance of enrolled children, improving quality of education, ensuring equity in education for all members of the society, effectively involving people in the planning and management of the education (Jain \& Kumar, 2013).

\subsection{Kasturba Gandhi Balika Vidyalaya (KGBV)}

Kasturba Gandhi Balika Vidyalaya (KGBV) was launched in 2004 for setting up residential schools at upper primary level for girls belonging to SC, ST, OBC and minority communities in educationally backward blocks of the country. The scheme was implemented in those blocks where female literacy was below the national average and gender gap in literacy was above the national average. Under this scheme, a minimum 75 per cent of seats are reserved for girls belonging to SC, ST, OBC or minority groups and 25 per cent seats are given to girls coming from families below the poverty line. From the enrolment trends, it has been observed that there remain significant gaps in the enrolment of girls at the elementary level as compared to boys especially at the upper primary levels, so the main objective of this scheme is to ensure access and quality education to the girls of disadvantaged groups of society by setting up residential schools with boarding facilities at the elementary level (Khandai, Khan \& Bhati, 2012).

\subsection{Mid-Day Meal Scheme, 1995}

The scheme of National Programme of Nutritional Support to Primary Education (NP-NPSE) commonly known as Mid-day Meal Scheme (MDM) was formally launched on $15^{\text {th }}$ August 1995 to boost the universalisation of primary education by increasing enrolment and retaining students in the government schools. The scheme has the goals to increase the attendance of the students and also to improve the nutritional status of children in primary education. The MDM is based on the idea that sound health is a precursor to providing education and so under this scheme, cooked meals with the minimum content of 300 calories of energy per day are served to all the students up to the elementary level for at least 200 days a year. The meal is prepared in the school under hygienic conditions. The scheme was revised several times and the scope of the scheme has been expanded to upper primary classes and also by including different types of schools in it from time to time, it also covers children studying in EGS centres and madrassah. It has been considered as the world's largest feeding programme of school children. The number of children covered under this scheme has increased from 3.34 crore in 1995 to 12 crores in 2007 (GOI, 2008).

The scheme had a positive effect on school attendance and the nutritional status of the children. It has catered to the nutritional needs of children from low-income families in both rural and urban areas. It has been observed that the MDM has led to increase in the enrolment of children in primary school especially the enrolment of girls, it also had a positive impact on enrolment of children from the disadvantaged sections of the society. The good practices in this scheme make the school environment more inviting for the students, but good MDM requires sound infrastructure, proper storage and cooking facilities etc. Many of the state governments have provided the facilities required for MDM and besides these many states also provide deworming medicines and micronutrients to the children with mid-day meal. However, some challenges, such as discrimination of children based on caste or socio-economic status, require immediate attention from the authorities. Besides improving the enrolment ratio in elementary education, it has other benefits also like increasing the attendance of the students in the school, improving their nutritional status and socialisation benefits (Khera, 2006). The EFA Report 
2015 also pointed out that this scheme improved the enrolment of girls in rural areas (UNESCO, 2015: 89). The recent global monitoring report applauded midday meal scheme of India in expanding the access to education among children from disadvantaged sections of the society (UNESCO, 2020)

\subsection{National Programme for Education of Girls at Elementary Level (NPEGEL)}

National Programme for Education of Girls at Elementary Level (NPEGEL) is a focused intervention of Government of India and an integral, yet separate, component of SSA launched in July 2003 to provide access and to facilitate retention of girls and to ensure equal participation of women and girls in the field of education. It is a gender distinct component to enhance girl's education by reaching the 'Hardest to reach' girls especially those not in school. The programme aims to improve the quality of a girl's education and stress upon their empowerment through quality education. The programme has been implemented through the Mahila Samakhya Unit of the SSA and in which districts Mahila Samakhya Unit is not operational, there the programme will be implemented through the sub-unit of SSA Society known as 'Gender Unit'. Model Cluster School (MCS) will be opened in the selected district or block. MCS will be girl-friendly school having girl child-friendly infrastructure and other facilities like teaching-learning equipment, books, games, computers etc. The scheme recognizes that the key to girls' education is community mobilization and so the cluster level group along with women volunteers, mother/ parents and other volunteers will work collaboratively to monitor the enrolment, attendance and achievement of girls (SSA, 2008).

\subsection{Sarva Shiksha Abhiyan (2000)}

From the above-mentioned programmes, some programmes such as Shiksha Karmi, and Lok Jumbish, were completed and others such as KGBV has been subsumed within Sarva Shiksha Abhiyan (SSA). SSA is a major and holistic programme for expanding access to universal elementary education and also for addressing the gender and social gaps at this level of education. The programme has been considered as a national movement for qualitative and comprehensive elementary education by providing interventions such as universal access and retention, eliminating gender and social gaps in elementary education and also for improving the quality of learning at this level of education. It is considered as a vehicle to operationalise the RTE Act (Jha and Parvati, 2014). This programme is the expression of political will and the main vehicle for achieving the universalisation of elementary education in the country, and its design has been built upon the prior experience of such programmes in primary education including District Primary Education Programme, Shiksha Karmi and Lok Jumbish (Chatterjee, 2011: 94). The programme has been applauded for reducing out of school children in the country (UNESCO, 2010).

\section{Educational Statistics}

The literacy rate of males and females along with gender gap from the year 1950 to 2015 has been tabulated and presented as follows:

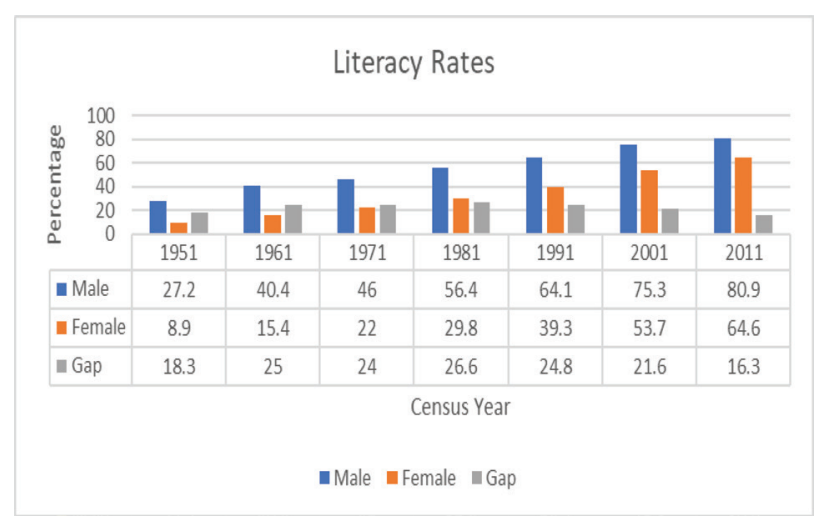

Chart 1: Female Literacy Rates.

(Source: Educational Statistics at Glace, MHRD, 2014)

In 1950, females had significantly lower literacy rates than males and this trend continues till present. No doubt, India has made considerable strides in increasing the literacy rates of males and females but the gender gap in literacy rates is still present. The literacy rates of India have increased from 18.1 per cent in 1951 to 72.75 per cent in 2011 and registered impressive progress. But on the other hand, the gender gap in literacy rates has reduced by only 2 per cent from 18.3 per cent in 1951 to 16.3 per cent in 2011 (MHRD, 2014).

The enrolment of girls in total enrolment for elementary education has been presented in Chart 2:

From the trend analysis of the enrolment data of various years, it has been observed that the enrolment of girls in Class VI-VIII remains significantly low as compared to boys. In 1950-51, the enrolment of girls 
was only 16 lakhs out of total enrolment of 67 lakhs in Class VI-VIII, then it followed an upward trend and in the year 2011-12, the enrolment of girls was 299 lakhs out of 630 lakh total enrolment. In the percentage form, the enrolment rate of girls was 23.88 per cent in 1950-51 session and it increased up to 47.46 per cent in the 2011-12 session. The increase in this percentage is more than double, but even in 2011-12, fewer girls were enrolled in elementary as compared to boys.

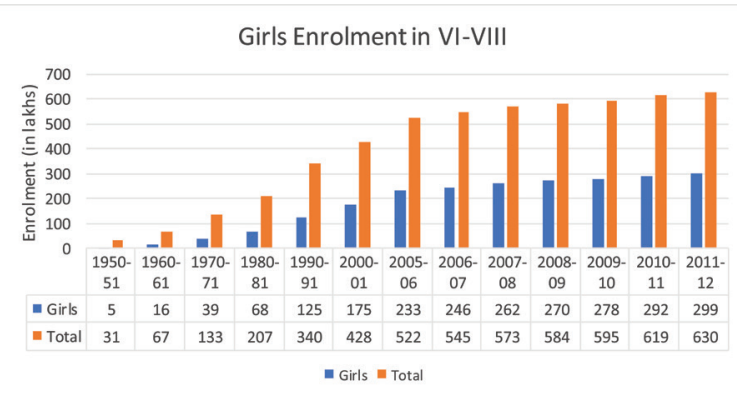

Chart 2: Enrolment of Girls in total Enrolment for the Classes VI-VIII. (Source: Educational Statistics at Glace, MHRD, 2014)

From the above charts and data, it can be predicted that to eliminate gender gaps in literacy rates and enrolment rates, India need intensified efforts in the form of clear-cut policies, strong political commitment, more innovative programmes and other such efforts. As it has been pointed out that gender gaps in education increased with the level of education and if there are gaps in school enrolment then these gaps continued till higher education. Furthermore, this inequality in access to education is also responsible for the loss of human development levels in the country (UNDP, 2010).

\section{Conclusions}

India remains quite proactive regarding the education of girls and has started many innovative programmes to eliminate gender gaps in school education. In various global education monitoring reports and human development reports, the efforts of India towards the education of girls and also for combating marginalization through the implementation of innovative programmes have been appreciated. The results of this study also attest this fact that the policies and programmes of the Government of India have resulted in the expansion of access to elementary education of girls. However, India needs more concerted efforts in bridging all social and gender gaps in school education as well as at higher education level to reap the maximum benefits from its demographic dividend. These programmes proved quite beneficial for reducing gender inequality in the elementary education level and so, such efforts should also be implemented for other levels of education.

It has been observed that the successful policies of one country often prompted other countries for the adoption of such policies. The RTE Act, 2009 of India motivated Pakistan to prepare its own RTE Act in 2012. The successful programmes of this kind can inspire the other countries struggling with disparities in access to education. With the help of these programmes, India has achieved enormous progress in gender parity in the elementary level of education and now the main focus should be placed on gender parity in secondary and higher level of education.

\section{Acknowledgements}

I thank Dr. Kamaljeet Singh, Professor, Punjabi University Regional Centre, Bathinda for his guidance and cooperation for this study.

\section{Authorship Contribution}

The main author has conducted and reported this study.

\section{References}

Best, J. \& Kahn, J.V. (2007). Research in Education. New Delhi: Prentice Hall.

Bhat, S.A. (2013). Millennium Development Goals: Achieve Universal Primary Education from Indian Perspective. International Journal of Scientific \& Research Publication, 3(11), 1-9.

Bowen, G.A. (2009). Document Analysis as Qualitative Research Method. Qualitative Research Journal, 9(2), 27-40.

Chatterjee, B. (2011). Education for all: The Indian saga. New Delhi: Lotus Press.

Dreze, J., \& Sen, A. (2013). An Uncertain glory-India and its contradiction. New Delhi: London Publication.

Government of India (1966). Education and National Development. Report of the Education Commission. Retrieved from https://archive.org

Government of India (1986). National Policy on Education, 1986 and Programme of Action, 1986. New Delhi: Department of Education, Ministry of Human Resource Development. 
Government of India (2009). The Right of Children to Free and Compulsory Education Act, 2009. New Delhi: Ministry of Human Resource Development.

Government of India. (2008). Eleventh Five Year Plan (2007-2012) Social Sector- Volume-II. New Delhi: Oxford University Press.

Government of India (2018). Samagra Shiksha Abhiyan: An Integrated Scheme for School Education- Framework for Implementation (Draft Document). New Delhi: Department of School Education and Literacy, Ministry of Human Resource Development.

Government of India (2019). The Constitution of IndiaAs on $1^{\text {st }}$ April 2019. GOI: Ministry of Law and Justice. Retrieved on November 5, 2019 from http:// legislative.gov.in/sites/default/files/COI-updated.pdf

Jain, A. \& Kumar, A. (2013). A Survey of Government Polices to Improve the Primary Education in Rajasthan. International Journal of Education and Psychological Research, 2(3), 133-142.

Jha, P., \& Parvati, P. (2014). Assessing Progress on Universal Elementary Education in India: A Note on Some Key Constraints. Economic \& Political Weekly, 49(16), 4451.

Kaur, S. (2018). International Policy Perspective for Universalisation of Primary Education in the Era of Globalisation. Online International Interdisciplinary Research Journal, 8(July-Aug 2018 Special Issue), 5258.

Kesarwani, D., \& Komaraiah, J.B. (2019). Determinants of women's enrolment in higher technical education in India: A Review. EduTech, 1901.

Khandai, H.K., Khan, S., \& Bhati, N.S. (2012). Primary Education. New Delhi: APH Publishing Corporation.

Khera, R. (2006). Mid-day meals in primary schools: Achievements and challenges. Economic and Political Weekly, 41(40), 4742-4750.

King, K. (2016). The Global Targeting of Education and Skill: Policy, History and Comparative Perspectives. Compare, 46(6), 952-975.

Ministry of Human Resource Development (2014). Educational Statistics at a Glance. Government of India. Retrieved on November 25, 2019 from https:// mhrd.gov.in/educational-statistics-glance-2014

Ministry of Human Resource Development (2018). Educational Statistics at a Glance. Government of India. Retrieved on November 29, 2019 from https:// mhrd.gov.in/sites/upload_files/mhrd/files/statisticsnew/ESAG-2018.pdf
Ministry of Human Resource Development (2020). National Education Policy 2020. Government of India. Retrieved on August 5, 2020 from https://static. pib.gov.in/WriteReadData/userfiles/NEP_Final_ English_0.pdf

Ramachandran, V. \& Sethi, H. (2001). Rajasthan Shiksha Karmi Project-An Overall Appraisal. Stockholm: Swedish International Development Cooperation Agency.

Sarva Shiksha Abhiyan. (2008). Revised guidelines for implementation of the 'National Programme for Education of Girls at Elementary Level' as a component of the scheme of Sarva Shiksha Abhiyan (SSA). New Delhi.

UNDP. (2010). Human Development Report 2010: The Real Wealth of Nations-Pathways of Human Development. New York: United Nations Development Programme.

UNDP (2016). Human Development Report 2016: Human Development for Everyone. New York: United Nations Development Programme.

UNESCO (2002). EFA Global Monitoring Report 2002: Education for All-Is the World on Track. Paris: United Nations Educational, Scientific and Cultural Organization.

UNESCO (2003). EFA Global Monitoring Report 2003/4: Gender and Education for All-the Leap to Equality. Paris: United Nations Educational, Scientific and Cultural Organization.

UNESCO (2010). EFA Global Monitoring Report 2010: Reaching the Marginalized. Paris: United Nations Educational, Scientific and Cultural Organization.

UNESCO (2015). EFA Global Monitoring Report 2015: Education for All 2000-2015: Achievements and Challenges. Paris: United Nations Educational, Scientific and Cultural Organization.

UNESCO (2017). Global Education Monitoring Report 2017/8: Accountability in Education-Meeting Our Commitments. Paris: United Nations Educational, Scientific and Cultural Organization.

UNESCO. (2020). Global Education Monitoring Report 2020: Inclusion and Education-All means All. Paris: United Nations Educational, Scientific and Cultural Organization. 


\section{芩 \\ CHITKARA}

\section{Issues and Ideas in Education}

Chitkara University, Saraswati Kendra, SCO 160-161, Sector 9-C, Chandigarh, 160009, India

Volume 8, Issue 2

September 2020

ISSN 2320-7655

Copyright: [ $₫ 2020$ Sarbjit Kaur] This is an Open Access article published in Issues and Ideas in Education (Issues Ideas Educ.) by Chitkara University Publications. It is published with a Creative Commons AttributionCC-BY 4.0 International License. This license permits unrestricted use, distribution, and reproduction in any medium, provided the original author and source are credited. 